\title{
Vad är en kropp?
}

Nora Simonhjell, Kroplingkroppar: om litterer framstilling av merkte, aldrande og funksjonshemma kroppar i Lars Ramslies Biopsi og Stig Saterbakkens Siamesisk, diss. Universitetet i Agder, Kristiansand 2009 (422 sidor)

VAD ÄR EN kropp? Frågan följer mig i läsningen av Nora Simonhjells avhandling Kroplingkroppar: om litterer framstilling av merkte, aldrande og funksjonshemma kroppar i Lars Ramslies Biopsi og Stig Saterbakkens Siamesisk. Frågan kan verka naiv och oskyldig, men under läsningen av Simonhjells avhandling förstår man snart att det är en både kritisk och politisk fråga som synliggör den paradoxalt oreflekterade och naturaliserade plats kroppen fortfarande har i både konst och teori.

Enligt Simonhjell har kroppen fyllt en symbolisk funktion i såväl litteraturen som litteraturvetenskapen - som representant för något annat - men sällan stått i fokus i egen rätt. Den funktionshindrade kroppen har också lyst med sin frånvaro i både litteratur och teori, även om en förändring skett under senare år. I diskussioner om identitet, subjektivitet och självförståelse diskuteras kroppar framförallt 
i termer av normer och avvikelser, ideal och överträdelser. Mer sällan undersöks kroppen som fysisk situation, som utgångspunkt för hur vi befinner oss i, tar oss fram i och förstår världen.

Syftet med Simonhjells avhandling är att visa hur de fysiska och materiella sidorna av kroppen får betydelse i två romaner - Ramslies Biopsi och Sæterbakkens Siamesisk. Med titeln Kroplingkroppar (på engelska crip, på svenska krympling) ansluter sig Simonhjell till det teoretiska och politiska projekt som de senaste decennierna pågått inom crip-forskningen (som i sin normkritik har ett släktskap med queerteoriska perspektiv): att återta och omvärdera de stigmatiserande tillmälen som historiskt sett har använts för att skilja ut avvikelser, i det här fallet funktionshinder. Med hjälp av teoretiska perspektiv hämtade från fältet disability-studies analyserar Simonhjell romanernas detaljerade skildringar av kroppslig förändring. När det gäller Biopsi ligger fokus både på hur kroppen förändras under ett livslopp och på den dramatiska förändring som sker genom en bilolycka och dess konsekvenser. Analysen av Siamesisk handlar om hur romanen gestaltar den gradvisa kroppsliga förändring som sker genom själva åldrandet och den successiva funktionsnedsättning som följer därur.

Simonhjell visar hur romanernas ingående och konkreta gestaltningar av märkta, åldrande och funktionsnedsatta kroppar ifrågasätter föreställningar om kroppen som en given utgångspunkt och neutral enhet. Detta är en av avhandlingens styrkor. I de ofta känsliga och komplexa analyserna av romanernas gestaltningar av det kroppsligt avvikande synliggör Simonhjell de allmänna villkoren för kroppslighet - dvs. att allas våra kroppar är stadda i förändring, åldrande, förfall och omskapande. Den kroppsliga skillnaden är inte en brist, utan det som gör en kropp till just den kroppen, eller för att tala med Simonhjells ord, det som gör kroppen "eineståande". Simonhjell menar att skönlitteraturen är särskilt lämpad för detta 
ändamål. Genom sin förmåga att förstora, koncentrera och tydliggöra mänskliga tillstånd förmår den ge andra perspektiv på mänsklig erfarenhet än de medicinska, natur- och samhällsvetenskapliga perspektiv som ofta har tolkningsföreträde i frågor om kropp, funktion och åldrande. En ambition med avhandlingen är också att visa å ena sidan hur skönlitteratur lämpar sig för studier av funktionalitet och kropp, å andra sidan hur litteraturanalyser kan berikas av perspektiv från det tvärvetenskapliga fältet disability studies.

Simonhjell kallar sin metod för "tematisk punktanalys". Genom att studera enskilda delar av texten där kroppsliga erfarenheter och processer står i centrum bygger hon upp större analytiska resonemang. Att fokusera på fragment är i det här sammanhanget en lyckad metod - det är inte i första hand romanerna som helheter, som konstnärliga gestaltningar med ett avsett eller icke avsett budskap eller tankeinnehåll som står i centrum. I centrum står de fragment som handlar om den fysiska kroppen och dess förändringar. Tillvägagångssättet är på en gång befriande och begränsande. Befriande eftersom kroppen just får undersökas i egen rätt, i egenskap av just kropp. Begränsande på så sätt att även om en kropp i litteraturanalyser inte ska reduceras till sitt symbolvärde, sin roll i en helhet, sin funktion som metafor för något annat - riskerar man inte att förlora öppningar och tolkningsmöjligheter när det metaforiska ledet skärs av? Som metod betraktad förstår jag dock denna tematiska punktanalys - den tvärvetenskapliga ansatsen och den teoretiska mångfalden i avhandlingen till trots - som en variant av den inom litteraturvetenskapen så utbredda närläsningen.

Just relationen mellan närläsningen av skönlitteraturen och de teoretiska perspektiven utgör både avhandlingens styrka och svaghet. Som bäst är Simonhjell när hon låter närläsningarna och de många teoretiska inspelen befrukta varandra, när man ser poängen av att anlägga ett "funkisperspektiv" på skönlitteraturen och när 
skönlitteraturens särskilda sätt att verka berikar de teoretiska perspektiven. Särskilt läsvärda är till exempel kapitel tio och elva som handlar om "ljus, syn, öga, synnedsättningar och blindhet" respektive "hörsel, ljud, hörselnedsättning och stillhet" i Siamesisk. Här visar Simonhjell på två saker. Dels litteraturens förmåga att tränga in i, undersöka och mejsla ut nyanserna i det mänskliga erfarenhetsområde som kallas "att se" eller "att höra" och dess förmåga att därmed bidra till den teoretiska problematisering som pågår bland annat inom disability studies. Dels att det är det teoretiska perspektivet som möjliggjort att just dessa motiv överhuvudtaget framträder som motiv, att de fokuseras och analyseras (jag ställer mig dock något frågande inför det faktum att såväl det fenomenologiska perspektivet som de nymaterialistiska, i dess sentida queera och feministiska tappningar, är så underutnyttjade).

Men det är också tillämpningen av teori som utgör avhandlingens problem. Även om Simonhjell bemödar sig om att vi ska förstå växelverkan och sambandet mellan litteratur och teori, mellan litteraturvetenskap och disability studies eller mellan litterära och utomlitterära erfarenheter så kvarstår i läsningen av avhandlingen ändå ofta frågan varför just litteratur? Allt för ofta parallellställs ett teoretiskt resonemang med en litterär gestaltning av samma fenomen utan att en fördjupning av någondera sker. Som ett exempel kan nämnas användningen av resonemang av Walter Benjamin, Roland Barthes och Judith Butler som parallellställs med skildringar i romanerna. Simonhjell refererar t.ex. Benjamins resonemang om fotografiets aura av här-och-nu, vilket relateras till Ramslies användning av ett sportfotografi: "Benjamin skriv om dei tidlege oppstilte og arrangerte fotografia. Poenget hans kan gjelde for sportsfotografia i dette fragmentet, sidan dei viser til det extraordinære. I benjaminsk forstand kan ein lokalisere 'den lille gnist av tilfeldighet' (ibid.) som kjernen i desse 
bilda.” (s. 94) Här fungerar alltså romanfragmentet som ett exempel på Benjamins resonemang och omvänt. Men det sker ingen direkt fördjupning - varken textfragment eller teori har förskjutits eller förändrats, de illustrerar bara varandra. Därmed inte sagt att Simonhjells analys av fragmentet med fotografiet inte är av vikt - tvärtom - men frågan är hur mycket av Benjamin som egentligen behövdes för att utföra den i sig själv nyanserade analysen och vice versa? Ett av flera exempel på samma fenomen är när Judith Butler refereras utan att ytterligare kommenteras i en passage som handlar om relationerna mellan makarna Mortens i Siamesisk: "Kjønn är ikkje lenger å forstå som reine kategoriar, men er derimot knytt opp til korleis ein handlar, og etter kjønnsteoretikaren Judith Butlers (1993) syn blir kjønn forstått performativt: noko som ein både er og gjer. Det eldre ekteparet Mortens held oppe eit gammalt og tradisjonelt kjønnsrollemønster." (s. 315) Resonemanget går sedan över till att handla om relationen mellan makarna. Frågan om kön och performativitet lämnas därhän utan att någon återkoppling till Butler sker och man frågar sig varför referensen alls skulle inleda detta avsnitt.

Det finns alltså både risker och möjligheter med att de teoretiska perspektiven parallellställs med, och hamnar på samma nivå som de skönlitterära texterna. Risken är att både teori och litteratur förlorar sin poäng som varandes just olika sätt att tänka - de får illustrera varandra istället för att förskjuta och påverka varandra. Möjligheten ligger - som Simonhjell också ofta övertygande visar - i att behandla romangenren som en kunskapsform, en specifik sådan, som säger oss något annat om mänsklig erfarenhet än vad andra kunskapsformer gör.

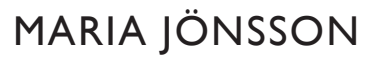

Umeå universitet 